\title{
発達障害とストレスチェック制度
}

\section{渡辺 登}

赤坂診療所

キーワード : 発達障害, ストレス, 産業医, 指導, ストレスチェック制度

(ストレス科学研究 2015, 30, 1-4)

\begin{abstract}
Industrial physicians who lack knowledge about developmental disorders cannot organize stories of both patients and their employers. This situation cause difficulties of taking countermeasures to the disorders. Therefore every industrial physician needs knowledge about developmental disorders.
\end{abstract}

Keywords: developmental disorder, stress, industrial physician, instruction, stress check system

\section{1.はじめに}

労働者のメンタルヘルス不調の予防を目的とした新 たな対策として，「ストレスチェック制度」を導入す る改正労働安全衛生法が2015年12月から施行される。 ストレスチェック制度を法制化した背景には以下に述 ベるような経緯がある。1998年に精神障害での労災認 定基準が定められて以降, 精神障害に起因する労災請 求件数は年々増加しており, 平成 25 年度 (平成 26 年 6月 27 日, 厚生労働省発表) では 1409 件と前年度より 152 件, 約 $12 \%$ の大幅増加となり, 過去最高となった。 また 2012 年の労働者健康状況調査では現在の仕事や 職業生活に関することで強い不安, 悩み, ストレスと なっていると感じる事柄がある労働者の割合は $60.9 \%$ と高いのにメンタルヘルスケアに取り組んでいる事業 所の割合は $47.2 \%$ に過ぎなかった。職場のストレッ サーと生じる不調を Table 1 に示した。さらに厚労省 の患者調査は精神障害患者数が 1996 年の 218 万人か ら 2011 年には 320 万人と大きく増えていると報告し ている。

これらの実態は職場では環境を改善・整備し, 人事 労務体制を見直し, 職員がメンタル疾患に罹患しない よう予防策に積極的に取り組む必要性を示唆する。
2014 年の労衝安全衛生法改正によって導入が決まっ たストレスチェックを含めた総合的な対策によって, 職員が自分の変化にいち早く気がつき, 不調に至る前 に善処できるよう取り組むのは, 職場に求められる支 援である。この対策が適切に運用され目的 (Table 2) が達成されるよう願っている。

\section{2. 面接指導の具体例}

上司の態度や職場環境に不満を抱き, メンタル不調 を覚えるため, 改善を訴える場を求めて職員がストレ スチェック制度をもとに産業医の面接指導を希望する 場合は少なくない。では面接指導ではどのようなこと が行われるのか Table 3，4で述べたい。

申し出る職員は, 適応障害やパーソナリティ障害, 発達障害（自閉症スペクトラム障害）などのタイプが 予想される。だが産業医は診断をつけることが仕事で はない。職員と職場との調整が役目である。調整で工 夫が欠かせない発達障害の例を紹介する。

\section{1 症例 25 歳 男性}

化学工業会社に入職して，物流担当係をしていた。 入社 3 年目の 2 月, 上司の指示に従い, 報告したとこ ろ同僚の前で怒鳴られた。それ以外でも, 同じ業務を 
Table 1 職場のストレッサーと生じる不調

\begin{tabular}{|c|c|c|}
\hline & 職場のストレッサー & 生じる不調 \\
\hline 1 & 職場の環境 & $\begin{array}{l}\text { 換気の悪さや騷音, 人間工学的問題などが, オフィスで働く人の心身に負担を与え } \\
\text { ている。重金属や有機溶剤などの有害物質が, 作業者の精神状態を悪化させる。 }\end{array}$ \\
\hline 2 & 役割の混乱 & $\begin{array}{l}\text { a 役割不明確 - 業務上の責任や期待が不明確 自信を失わせ, 仕事から満足を得 } \\
\text { られない。緊張, うつ気分を起こしやすい。 } \\
\text { b 役割葛藤一矛盾する指示や人事業務をどのように進めていってよいのか, 分か } \\
\text { らなくなる。仕事に手がつかず, 緊張が高まる。 }\end{array}$ \\
\hline 3 & 人間関係 & $\begin{array}{l}\text { 同僚や上司とのトラブル及び人的支援がないことは，うつ気分や職場放棄につなが } \\
\text { る。心臓病や脂質異常症を起こしたする }\end{array}$ \\
\hline 4 & 技術を活かせない & 習得した技術を発揮できる場や機会がないと，業務への意欲を低下させる。 \\
\hline 5 & 業務決定の自由度 & 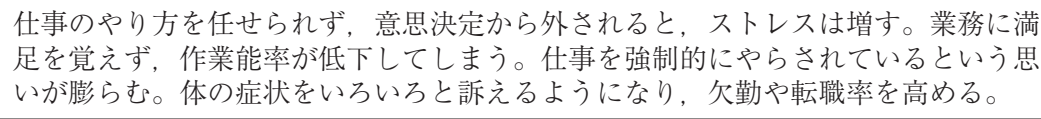 \\
\hline 6 & 量的あるいは質的な作業負担 & 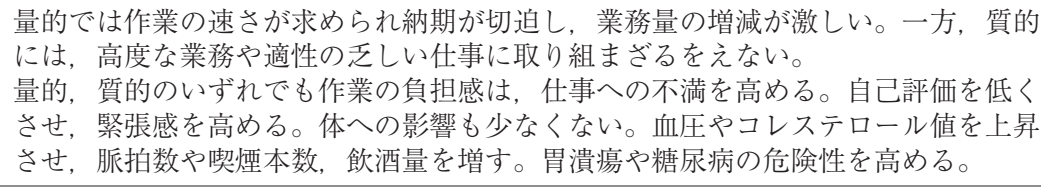 \\
\hline 7 & 将来への不安 & $\begin{array}{l}\text { 雇用の不安定や昇進・昇給の遅れ, 解雇の恐れなどが, 仕事や生活での満足感を減 } \\
\text { らし, 将来が見通せなる。 }\end{array}$ \\
\hline 8 & 勤務形態 & 交代勤務や夜勤は, 死亡率や消化器系·循環器系疾患の発病率を高める。 \\
\hline 9 & 仕事と私生活との葛藤 & $\begin{array}{l}\text { 仕事量が多いため, 家庭生活に支障を来す。夫婦間のストレスを高め, 余㗇の時間 } \\
\text { を減らす。家庭に戻っても，仕事のことを考え，気が休まらない。逆に，私生活の } \\
\text { トラブルが仕事への集中力を損なわせることもある。 }\end{array}$ \\
\hline & 技術革新 & $\begin{array}{l}\text { 機械に支配される作業形態は，仕事を自分が行っているという主体性を失わせる。 } \\
\text { 定型作業の繰り返しや生産性向上にともなう業務量の急増は，心身の不調を招く。 }\end{array}$ \\
\hline
\end{tabular}

Table 2 ストレスチェック制度の目的

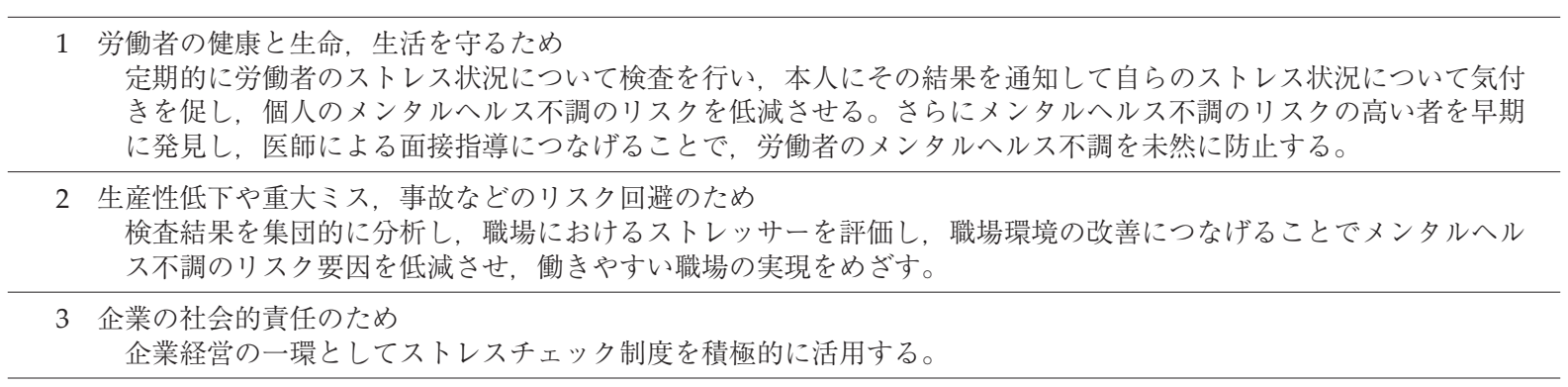

Table 3 面接指導において医師が確認する事項

\begin{tabular}{lll}
\hline 1 & 当該労働者の勤務の状況 & 労働時間, 業務の内容等について予め事業者から情報を入手 \\
\hline 2 ストレッサー & 職場の人間関係や前回検査以降の業務・役割の変化の有無等 \\
\hline 3 & 心理的な負担の状況 & 抑うつ症状等 \\
\hline 4 & 周囲のサポート状況 & 上司や同僚, 産業保健スタッフらのサポート \\
\hline 5 心身の状況の確認 & $\begin{array}{l}\text { 過去の健診結果や現在の生活の状況の確認を含む。必要に応じてうつ病等やストレス関 } \\
\end{array}$ & $\begin{array}{l}\text { 連疾患 (胃・十二指腸潰瘍, 高血圧症, 気管支ぜんそく, 顎関節症等の疾患でストレス } \\
\text { が関連するもの)をを念頭においた確認を行う。 }\end{array}$ \\
\hline
\end{tabular}

している先輩に「報告がない」といびられた。真面目 に仕事をしているのに，なぜ叱責されたり，意地悪さ れたりするかの理由が思いつかなかった。対人関係で の重圧に加えて，業務の多忙で自信を失い不眠がちと
なり，気持ちが落ち込んでいった。

職場で受けたストレスチェックの結果は「高ストレ ス者」だった。上司や会社に不信感を持っていたので, さっそく産業医の面接指導を求めた。今までの経過を 
Table 4 面接指導において医師が労働者に対して医学上の指導を行う事項

\begin{tabular}{|c|c|}
\hline 1 & $\begin{array}{l}\text { 保健指導 } \\
\quad \text { ・ ストレ対処技術の指導 } \\
\quad \text { 自覚と自主努力 (セルフケア, 受療への努力の重要性の認識と指導 }\end{array}$ \\
\hline 2 & $\begin{array}{l}\text { 受診指導（面接指導の結果, 必要に応じて実施） } \\
\text { ·専門機関の受診の勧桨と紹介 } \\
\text { 面接指導において, メンタルヘルス不調者を把握した場合には, 必要があれば医師の判断により継続的な対応 } \\
\text { を行いたい。また必要に応じて, 精神科等の専門医療につなげる。 }\end{array}$ \\
\hline & Table 5 上司からの情報 \\
\hline 1 & $\begin{array}{l}\text { 情報をため込み, 適切な時期に送信しない } \\
\text { 事業や業務処理に最低限必要な情報は何なのか, 重要性の程度を把握していない。そのため, 職場内外の関係者に } \\
\text { 必要な情報を必要な時に, 必要な相手に伝えることができなかった。 }\end{array}$ \\
\hline 2 & $\begin{array}{l}\text { 優先順位をつけられない } \\
\text { どのような順番で処理すべきか優先度をつけること, どの程度の重要性で取り組むべきか判断すること, いつまで } \\
\text { に処理すべきか, スケジュール管理ができなかった。 }\end{array}$ \\
\hline 3 & $\begin{array}{l}\text { 注意された内容が理解できない } \\
\text { 情報の伝達がうまくいかず, ミスが発生することが頻繁にあった。その後に, 振り返りのミーティングを開いたが, } \\
\text { その結果が次回に活かされない。終わってしまえば, 途中のミスがどうあろうとも関係ないと考えているようだ。 }\end{array}$ \\
\hline 4 & $\begin{array}{l}\text { 落ち着きのなさ } \\
\text { 机の引き出しを, 音を立てて押しこむ, PCのキーボードを, 音を立てて吒く, 離席が頻回, 貧そ摇すり, ウロウ } \\
\text { ロ歩く。イライラした行動で周囲の人を苛立たせても, 迷惑をかけているとの反省はない。 }\end{array}$ \\
\hline
\end{tabular}

Table 6 当事者本人への工夫の提案

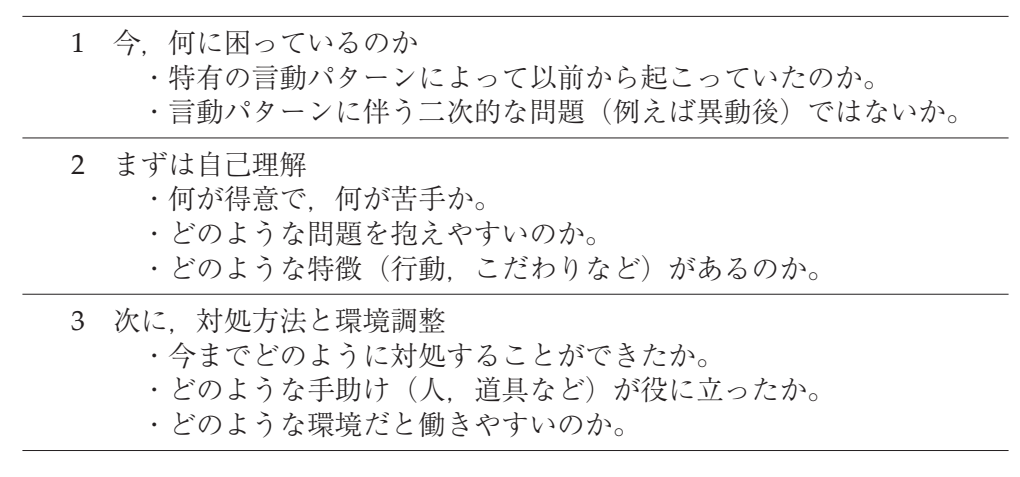

産業医に説明して, 上司の態度や職場の改善を強く訴 えた。「上司の態度は許せない。私だけ業務量が多い のは不満だ。減らして欲しい」。

彼の訴えは意外にも，あらかじめ上司から得ていた 情報とでズレがあった。彼は上司から叱責された理由 を理解してなかった。さらに業務量の多さは本人の作 業効率の悪さが原因であり, 同僚と比べて業務量は少 ないくらいだった。職場での自分の働きぶりや言動が, 職場や同僚にどのような迷惑をかけていたのか客観的 に振り返ることはなかった。自覚しないまま, 一方的 に相手の非をあげつらっていた。上司からの情報を Table 5 で示した。

こうした社員が産業医の面接指導を求める場合は少 なくないだろう。上司や会社の態度に不満を抱き, 改 善を訴える場を求めているからだ。厚生労働省の指針 には，産業医が適切な面接指導を行うために，事業者
はあらかじめ社員の勤務状況や職場環境などの情報を 提供すると書いてある。情報の真偽や裏付けなどを検 討した後に, 産業医は面接指導に入る。もし, 情報や 精神医学的知識を欠いたまま本人の主張を基に上司や 会社の対応を求めると職場を混乱させる。今回の本誌 特集は, ストレスチェック制度が職場に導入されるに あたり時機を得た内容である。

なお，新型うつ病と呼ばれている社員のなかには， 発達障害に双極性 II 障害（うつ状態に加え, 軽躁状態 が起こる双極性障害を「双極II 型障害」と呼ぶ）や適 応障害を併存したケースも混じっている。発病前から 職場でのコミュニケーションや複雑な業務処理, 臨機 応変が不得手であれば，ひょっとしたら基礎疾患に発 達障害があるかも知れないと考えたい。

発達障害の社員がメンタル不調を招くきっかけは, 環境の変化や良き理解者の消失である。職場や業務, 
Table 7 職場の同僚への説明

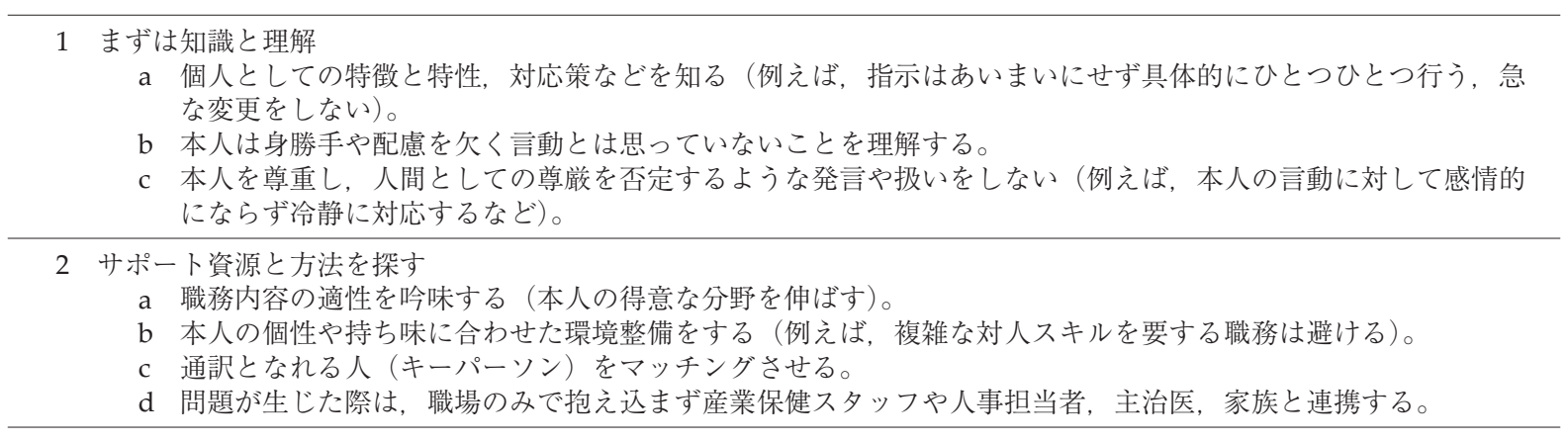

上司が変わる，もしくはフォローしてくれる同僚がい なくなる，部下が付くなどの理由で管理能力を求めら れるなどでパニックに陥る。場の雲囲気やチームプレ イを重んじる上司や，常識や建前にとらわれる上司の 下で働くことになると，たちまち不調をきたす。

また発達障害には不向きな仕事が多い。接客業や営 業職，中間管理職，教職などチームで動く仕事や臨機 応変に対応しなければならない仕事は苦手であり, 不 適応を起こして長続きしない。良き理解者がいれば幸 いだが，いない場合には周囲に合わせようとすればす るほど空回りして, やがてうつ状態や身体症状が起 こってしまう。

メンタルヘルス不調のリスク要因を低減させ, 働き
やすい職場の実現をめざすために，産業医は職場と職 員の間に立って, Table 6, 7 のように調整をするのが 重要な役割である。

\section{3. おわりに}

産業医が発達障害についての知識がそしいと，スト レスチェック制度をもとに面接した社員の訴えと上司 からの情報を適切に整理できない。話のズレに困惑 し，必要な措置を講じられない。そこで社員に不利益 な取り扱いが及ばないよう対策案を立てるためにも本 誌特集を中心とした発達障害についての知識が欠かせ ない。 